\title{
KINERJA PENYULUH PERTANIAN DALAM MASA PANDEMI COVID-19 DI KELURAHAN TARATARA SATU KECAMATAN TOMOHON BARAT KOTA TOMOHON
}

\section{THE PERFORMANCE OF AGRICULTURAL EXTENSION WORKERS DURING THE COVID-19 PANDEMIC AT SUB DISTRICT TARATARA SATU OF WEST TOMOHON DISTRICT TOMOHON CITY}

\author{
Hiskia Engelbert Tandibato_(1), Rine Kaunang ${ }^{(2)}$, Meisje Yellie Memah_ ${ }_{-}^{(2)}$ \\ 1) Mahasiswa Program Studi Agribisnis, Fakultas Pertanian, Universitas Sam Ratulangi, Manado \\ 2) Dosen Program Studi Agribisnis, Fakultas Pertanian, Universitas Sam Ratulangi, Manado \\ *Penulis untuk korespondensi: hiskiatandibato034@student.unsrat.ac.id
}

\begin{abstract}
This research aims to figure out about the agricultural extension worker's performance of their main tasks at Sub-District Taratara Satu, Tomohon City. The types of data used in this study are primary and secondary data obtained through direct interviews with farmers and through questionnaires. The sampling method that's being used in this study is Purposive Sampling Method; where the researcher chooses the respondents themselves from the farmers. This research used descriptive analysis that namely explaining the data obtained by using words that are assisted by data tables. This research shows that the performance of agricultural extension workers; which can be measured from the main task of extension workers where the results tend to be good because agricultural extension activities are only focused on agricultural core activities. Such as agricultural programs, technical meetings, demonstrations, and courses for the farmers.
\end{abstract}

Keywords: Covid-19 pandemic; performance; agricultural extension; change

\begin{abstract}
ABSTRAK
Penelitian ini bertujuan untuk mengetahui kinerja penyuluh dari tugas pokok penyuluh, di Kelurahan Taratara Satu, Kota Tomohon. Penelitian ini dilaksanakan selama satu bulan dari bulan Desember 2020 sampai bulan Januari 2021. Jenis data yang digunakan dalam penelitian ini adalah data primer dan sekunder yang diperoleh melalui wawancara langsung pada 10 petani yang dipilih secara sengaja (purposive sampling). Wawancara dilakukan berdasarkan kuesioner yang telah disiapkan sebelumnya. Penelitian ini menggunakan analisis deskriptif. Data sekunder dikumpulkan dari Kantor Desa Kelurahan Tara-tara Satu. Hasil penelitian ini menunjukkan bahwa kinerja penyuluh pertanian, yang diukur dari tugas pokok penyuluh, hasilnya berada pada kategori baik karena kegiatan penyuluh pertanian hanya difokuskan pada kegiatan inti pertanian yakni program pertanian, pertemuan teknis, demonstrasi, dan kursus untuk petani.
\end{abstract}

Kata Kunci: Pandemi Covid-19; kinerja; penyuluh pertanian; perubahan 


\section{PENDAHULUAN}

\section{Latar Belakang}

Sektor pertanian memiliki peranan yang sangat penting dalam mendukung perekonomian nasional Indonesia. Peran tersebut terutama dalam terciptanya ketahanan pangan, penyumbang produk domestik bruto, penciptaan lapangan pekerjaan dan penanggulangan kemiskinan, penyedia bahan pangan dan bahan baku industri, sumber pendapatan masyarakat, serta penciptaan iklim yang kondusif bagi pertumbuhan sektor lainnya (Kementan, 2014). Tantangan besar akan dihadapi sektor ini untuk selalu berinovasi menghadapi persaingan global. Dalam menjawab tantangan tersebut, diperlukan sumber daya manusia pertanian yang andal, berkualitas, dan mempunyai kemampuan. Hal tersebut harus wajib dimiliki para pelaku pembangunan dalam sektor pertanian. Pembangunan kualitas pelaku utama dan pelaku usaha pertanian dapat dilakukan melalui pendidikan dan penyuluhan pertanian.

Semenjak virus corona atau (Covid-19) diberitakan muncul di Tiongkok (China) dan menyebar ke seluruh dunia, banyak negara yang mulai melakukan screening terhadap semua yang masuk ke negeranya masing-masing. Hal ini membuat setiap orang yang melakukan perjalanan keluar masuk suatu negara dipantau, tak terkecuali barang atau benda berupa bahan mentah industri maupun bahan pangan. Hal ini berdampak pada semua sektor industri yang ada di seluruh dunia, tak terkecuali industri dalam sektor pertanian. Dengan diberlakukannya screening maka semua barang yang masuk kesetiap negara di pantau dengan ketat. Dampaknya sangat nyata dalam pertumbuhan ekonomi di seluruh dunia.

Di Indonesia sendiri, ketika pemerintah secara resmi mengumumkan bahwa Covid-19 masuk ke Indonesia, pemerintah dengan cepat bertindak untuk menetapkan protokol kesehatan agar masyarakat bisa terhindar dari paparan Covid-19. Protokol kesehatan yang digagas pemerintah Indonesia tentunya sangat berdampak bagi perekonomian negara dalam banyak sektor.
Tetapi dari data yang diperoleh dari Badan Pusat Statistik (BPS) tahun 2020 terlihat bahwa perekonomian di sektor pertanian tidak mengalami penurunan, walaupun perekonomian Indonesia secara keseluruhan mengalami penurunan, tapi tidak untuk sektor pertanian. Telah dibuktikan beberapa kali bahwa sektor pertanian menjadi benteng penyelamat perekonomian negara, terbukti pada krisis moneter pada 1998 lalu. Sektor pertanian menjadi salah satu sektor mampu bertahan dan menjadi penyanggah bagi sektor-sektor lainnya yang mengalami kemunduran dan kemerosotan pada krisis moneter tahun 1998. Badan Pusat Statistik (2020) merilis bahwa PDB (Produk Domestik Bruto) sektor pertanian menjadi penyumbang tertinggi dalam pertumbuhan ekonomi nasional pada triwulan II 2020 yang mengalami penurunan $5,32 \%$. Sektor pertanian ini tumbuh sebesar $2,80 \%$ pada triwulan II 2020. PDB pertanian tumbuh $16,24 \%$ pada triwulan II 2020. Ekspor komoditas pertanian mengalami kenaikan sebesar 9,67\% jika dibandingkan dengan periode yang sama tahun sebelumnya.

Peran para petani dalam rantai pasok makanan sangatlah penting di masa pandemi Covid-19. Terjadi banyak perubahan di hampir seluruh negara di dunia. Setiap negara di dunia berusaha untuk memenuhi kebutuhan pangan domestiknya masing-masing karena jalur perdagangan internasional terganggu semenjak wabah Covid-19 menyebar. Produksi dalam negeri sendiri menjadi tumpuan utama setiap negasa saat ini, termasuk Indonesia. Fasilitas produksi antara lain seperti mesin dan peralatan pertanian, subsidi pupuk dan benih, serta fasilitas pendukung produksi lainnya, perlu menjadi prioritas bagi peningkatan produksi dalam negeri. Bantuan dan fasilitas dari stake holder terkait dibutuhkan agar petani dapat meningkatkan produksinya. Selain itu, diperlukan juga protokol produksi yang dapat menjamin kualitas dan keamanan pangan yang terbebas dari Covid-19.

Pemerintah Indonesia melalui penyuluh pertanian yang ada di setiap kecamatan terus berupaya untuk melakukan pendampingan dan memfasilitasi dalam pengembangan kualitas pelaku utama dan pelaku usaha pertanian. Peran 
penyuluhan dalam penyelenggaraan lebih mengarah pada perubahan berencana. Boyle (1981) dalam Nuryanto (2008) mengemukakan bahwa perubahan berencana sebagai kegiatan yang disadari, sengaja dan bersama-sama untuk meningkatkan suatu sistem sosial secara operasional, baik itu sistem sosial sendiri, sistem sosial atau sistem kebudayaan melalui pemanfaatan pengetahuan yang tepat. Perubahan yang diinginkan atau berencana, harus diidentifikasi dan ditentukan. Perubahan tersebut merupakan deskripsi dari kondisi antara yang ada dan yang seharusnya ada. Perubahan yang direncanakan tersebut membutuhkan peran penyuluh. Levin dalam Nuryanto (2008), penyuluh mempunyai peran utama, yaitu: (1) peleburan diri dengan masyarakat sasaran; (2) mengarahkan masyarakat untuk melakukan perubahan berencana; dan (3) memantapkan hubungan sosial dengan masyarakat sasaran.

Melalui Instruksi Presiden (Inpres No. 6 Tahun 2020) tentang Peningkatan Disiplin dan Penegakan Hukum Protokol Kesehatan Dalam Pencegahan dan Pengendalian Corona Virus Disease 2019, yang berlaku sejak 4 Agustus 2020. Inpres yang telah ditetapkan oleh pemerintah tentunya akan sangat berpengaruh pada kinerja penyuluh dalam melaksanakan tugas, terlebih ketika penyuluh melakukan kegiatan di lapangan. Salah satu aturan dalam protokol kesehatan adalah menghindari kerumunan dan dilarang melakukan kegiatan yang dapat mengumpulkan orang dalam jumlah yang banyak.

Masa pandemi Covid-19 sekarang ini, peranan penting penyuluh pertanian sangat diharapkan terutama dalam menyokong penyediaan bahan pangan. Dalam menjamin ketersediaan bahan pokok utama seperti beras dan jagung bagi 267 juta masyarakat Indonesia, maka penyuluh pertanian harus bisa memastikan bahwa pertanian jalan terus. Penelitian ini bertujuan untuk mengetahui kinerja penyuluh pertanian dalam masa pandemi Covid-19 dan untuk mengetahui faktor-faktor yang mempengaruhi kinerja penyuluh pertanian selama masa pandemi Covid-19 ini. Kinerja penyuluhan yang dimaksud dalam penelitian ini mengacu pada
Permentan No. 91 Tahun 2013 tentang Pedoman Evaluasi Kinerja Penyuluh Pertanian. Di dalam pedoman ini, indikator penilaian kinerja meliputi perencanaan penyuluhan, pelaksanaan penyuluhan, evaluasi, dan pelaporan penyuluhan. Indikator yang digunakan dalam penelitian ini adalah perencanaan dan pelaksanaan penyuluhan.

\section{Konsep Kinerja}

Sondang Siagian (2002) menjelaskan bahwa bagi individu penilaian kinerja berperan sebagai umpan balik tentang berbagai hal seperti kemampuan, keletihan, kekurangan dan potensinya yang pada gilirannya bermanfaat untuk menentukan tujuan, jalur, rencana dan pengembangan karirnya. Sedangkan bagi organisasi, hasil penilaian kinerja sangat penting dalam kaitannya dengan pengambilan keputusan tentang berbagai hal seperti identifikasi kebutuhan program pendidikan dan pelatihan, rekrutmen, seleksi, program pengenalan, penempatan, promosi, sistem balas jasa, serta berbagai aspek lain dalam proses manajemen sumber daya manusia. Berdasarkan kegunaan tersebut, maka penilaian yang baik harus dilakukan secara formal berdasarkan serangkaian kriteria yang ditetapkan secara rasional serta diterapkan secara objektif serta didokumentasikan secara sistematik.

\section{Penyuluh Pertanian}

Penyuluh pertanian adalah orang yang mengemban tugas memberikan dorongan kepada petani agar mau mengubah cara berpikir, cara kerja dan cara hidupnya yang lama dengan caracara baru yang lebih sesuai dengan perkembangan zaman dan perkembangan teknologi pertanian yang lebih maju (Kartasapoetra, 1994). Penyuluh pertanian sebagai seorang yang mempunyai status dimasyarakat, juga mempunyai peranan yang penting dalam mendukung pembangunan pertanian. Secara konvensional peranan penyuluh hanya dibatasi oleh kewajiban dalam menyampaikan inovasi dan mempengaruhi sasaran (petani), namun dalam perkembangannya, peran penyuluh pertanian tidak hanya terbatas pada fungsi penyampaian inovasi, tetapi juga harus mampu menjembatani antara pemerintah atau lembaga penyuluh yang bersangkutan (Gitosaputro, dkk, 2012). 


\section{Rumusan Masalah}

Adapun rumusan masalah dari penelitian ini adalah bagaimana kinerja penyuluh pertanian dalam masa pandemi Covid19 khususnya di Kelurahan Taratara Satu, Kecamatan Tomohon Barat, Kota tomohon?

\section{Tujuan Penelitian}

Penelitian ini bertujuan untuk Mengetahui dan mendeskripsikan kinerja penyuluh pertanian pada masa pandemic Covid-19 di Kelurahan Taratara Satu, Kecamatan Tomohon Barat, Kota Tomohon.

\section{Manfaat Penelitian}

Adapun manfaat dari penelitian ini nantinya yaitu:

1. Sebagai wahana bagi peneliti dalam penerapan dan pengembangan ilmu pengetahuan yang dimiliki dengan kenyataan yang ada di lapangan.

2. Dapat menambah pengetahuan bagi peneliti agar lebih memahami tentang kinerja pertanian pada masa pademi Covid-19

\section{METODE PENELITIAN}

\section{Waktu dan Tempat Penelitian}

Penelitian ini dilaksanakan selama satu bulan dari bulan Desember 2020 sampai bulan Januari 2021 yang berlokasi di Kelurahan Taratara Satu, Kecamatan Tomohon Barat, Kota Tomohon, Provinsi Sulawesi Utara.

\section{Metode Pengumpulan Data}

Data yang di gunakan dalam penelitian ini adalah data primer dan data sekunder. Data primer diperoleh melalui wawancara secara langsung dengan petani di Kelurahan Taratara Satu Kecamatan Tomohon Barat Kota Tomohon Provinsi Sulawesi Utara. Metode pengumpulan data dilakukan dengan cara pemberian angket (Questionnaire) yang berasal dari objek yang dileliti yaitu petani di Kelurahan Taratara Satu Kecamatan Tomohon Barat. Untuk diisi kemudian lembar kuisioner dikumpulkan, diolah dan kemudian dianalisis.

\section{Metode Pengambilan Sampel}

Pengambilan sampel dalam penelitian ini dilakukan secara sengaja (purposive sampling) dan yang menjadi responden yaitu petani padi dari 2 kelompok tani yaitu kelompok tani Maanar Oki dan kelompok tani Lewet yang ada di Kelurahan Taratara Satu dan diambil sebanyak 10 orang petani yang ditentukan oleh ketua kelompok tani sebagai perwakilan kelompok- kelompok tani tersebut.

\section{Konsep Pengukuran Variabel} ini adalah:

Variabel yang diukur dalam penelitian

1. Karakteristik Responden

a. Jenis Kelamin : Laki-laki / Perempuan

b. Umur : Usia responden (tahun)

c. Tingkat Pendidikan : Lama mengenyam pendidikan

2. Untuk mengetahui kinerja penyuluh pertanian dalam masa pandemi Covid-19 di Kelurahan Taratara Satu Kecamatan Tomohon Barat Kota Tomohon Provinsi Sulawesi Utara, variabel yang diukur sebagai berikut :

a. Program penyuluhan penyuluh

b. Pertemuan berkala penyuluh

c. Pertemuan teknis, demonstrasi, dan kursus oleh penyuluh.

d. Penyuluh melakukan pengembangan organisasi petani.

e. Penyuluh melakukan penegmbangan organisasi petani

f. Peyuluh melatih dan mengembangkan kepemimpinan petani

g. Fasilitas pengembangan media informasi untuk penyuluhan pertanian

h. Penyuluh melatih petani dalam melakukan kerjasama dengan lembaga lain

i. Penyuluh melaksanakan studi banding antar kelompok tani.

\section{Metode Analisis Data}

Penelitian ini menggunakan analisis deskriptif, yaitu menjelaskan data yang di peroleh dengan menggunakan kata-kata dan dibantu dengan tabel data. 


\section{HASIL DAN PEMBAHASAN}

\section{Deskripsi Daerah Penelitian}

\section{Sejarah Kelurahan Letak dan Luas Wilayah}

Taratara pada tahun 1303 sejumlah Tonaas (pimpinan adat) yang berasal dari Sarongsong-Toumuung mengadakan suatu perjalanan untuk pergi membuat garam di sekitar pantai Tambala Tanawangko. Oleh karena lintasan perjalanan terhenti saat matahari mulai terbenam, dan akhirnya mereka bermalam disekitar mata air yang sekarang disebut "Kemer". Di sekitar mata air tersebut terdapat rawa-rawa yang ditumbuhi sejenis rumbut- rumputan yang berbunga, ketika diinjak orang akan berbunyi 'Taz-Taz'.

Kemudian Tonaas mendengar bunyi burung "manguni makasiow" lalu disitu mereka mendirikan "popo" atau Lawih (sejenis tenda). Waktu itu lokasi yang dijadikan peristirahatan mereka diberi tanda 'watu tinalingaan' yang saat ini ada di lingkungan Delapan Kelurahan Taratara Dua kira-kira berjarak 50meter dari Gereja GMIM Immanuel Taratara.

Dari asal kata rumput atau bunga yang tumbuh di rawa itu, kemudian ditambahkan huruf a dibagian akhir menjadi Taza-Taza dan oleh Hukum Tua bernama Wilar menyebut Taratara. Sekitar tahun 1916-1933 di masa Hukum Tua W. Pongoh, status Taratara menjadi Onder District Tombariri, dengan kantor Hukum Ketua berada di Taratara. Nanti setelah diera tahun 1946 Taratara akhirnya masuk di wilayah District Tomohon. Yang kemudian berkembang menjadi Kecamatan Tomohon.

Taratara pada tahun 1978 dimekarkan menjadi dua. Desa Taratara Satu dengan Hukum Tua Romaldus Turambi dan Taratara Dua dengan Hukum Tua Hanoch Z Pandey (1978-2002). Status Desa Taratara Dua menjadi Kelurahan setelah didirikannya Kota Tomohon pada tahun 2004 dan selanjutnya dimekarkan pada tanggal 07 September tahun 2009 sesuai dengan peraturan daerah Kota Tomohon No. 12 tahun 2009. Itulah sejarah singkat Kelurahan Taratara yang dikutip dari buku sejarah Desa Taratara yang ada di kantor kelurahan.

\section{Letak dan Luas Wilayah}

Kelurahan Taratara Satu terletak di Kecamatan Tomohon Barat tepatnya dibawa kaki gunung Lokon, Gunung Kasehe. Masyarakat Kelurahan Taratara satu memiliki mata pencaharian rata-rata adalah petani $(85 \%)$ ini dapat dilihat dari kawasan perkebunan masyarakat yang ditanami pohon kelapa, cengkeh, serta terdapat daerah persawahan dan ladang yang ditanami padi dan jagung serta komoditi hortikultura lainnya.

Kelurahan Taratara Satu merupakan salah satu Kelurahan yang terletak di Kecamatan Tomohon Barat dengan luas wilayah yaitu $626 \mathrm{Ha}$, terbagi dalam luas pemukiman $20 \mathrm{Ha}$, luas persawahan $250 \mathrm{Ha}$, luas perkebunan $350 \mathrm{Ha}$, luas pekarangan 4,5 Ha, luas taman, perkantoran dan prasarana umum lainnya masing-masing luasnya berjumlah 0,5 Ha. Secara administrasi terbagi dalam 8 Lingkungan. Dengan batas-batas wilayah sebagai berikut:

1. Sebelah utara berbatasan dengan Kelurahan Taratara Dua.

2. Sebelah selatan berbatasan dengan Kelurahan Taratara Dua.

3. Sebelah timur berbatasan dengan Kelurahan Pinaras dan Desa Tincep.

4. Sebelah barat berbatasan dengan Kelurahan Taratara dan Desa Ranotongkor.

\section{Karakteristik Responden}

Ada 19 kelompok tani yang ada di Kelurahan Taratara Satu, dipilih 2 kelompok tani yakni kelompok tani Maanar Oki dan kelompok Tani Lewet selanjutnya dari dua kelompok tani tersebut diambil 10 orang petani, masing-masing ketua, wakil ketua, bendahara, dan 2 anggota untuk dijadikan responden dalam penelitian ini.

\section{Berdasarkan Jenis Kelamin}

Adapun distribusi responden dalam penelitian ini dapat dijelaskan berdasarkan jenis kelamin dan hasil yang diperoleh dapat dilihat sebagai berikut.

Tabel 1. Karakteristik Responden Berdasarkan Jenis Kelamin

\begin{tabular}{llcc}
\hline No. & Jenis Kelamin & \multicolumn{2}{c}{ Jumlah } \\
\cline { 3 - 4 } & & Responden (Orang) & Persentase \% \\
\hline 1. & Pria & 9 & 90 \\
2. & Wanita & 1 & 10 \\
\multicolumn{2}{c}{ Total } & $\mathbf{1 0}$ & $\mathbf{1 0 0}$ \\
\hline \multicolumn{2}{l}{ Sumber : Diolah dari data kuesioner, 2021 }
\end{tabular}


Tabel 1 menunjukkan bahwa sebagian besar responden adalah pria sebanyak 9 orang dengan persentase sebesar $90 \%$ sedangkan responden wanita sebanyak 1 orang dengan persentase $10 \%$.

\section{Berdasarkan Umur}

Umur petani merupakan salah satu faktor penentu yang penting karena berpengaruh pada kemampuan fisik petani dalam suatu pekerjaannya. Secara umum dapat dikatakan bahwa seseorang yang berumur mudah akan mempengaruhi fisik yang lebih tinggi dan lebih banyak melakukan aktivitas dan lebih muda menerima pengetahuan serta inovasi baru. Adapun karakteristik responden berdasarkan umur, dan hasil yang diperoleh dapat dilihat sebagai berikut :

Tabel 2. Karakteristik Responden Berdasarkan Umur

\begin{tabular}{|c|c|c|c|}
\hline \multirow[t]{2}{*}{ No. } & \multirow{2}{*}{$\begin{array}{l}\text { Umur } \\
\text { (Tahun) }\end{array}$} & \multicolumn{2}{|c|}{ Jumlah } \\
\hline & & $\begin{array}{c}\text { Responden } \\
\text { (Orang) }\end{array}$ & $\begin{array}{c}\text { Persentase } \\
\%\end{array}$ \\
\hline 1. & $50-60$ & 7 & 70 \\
\hline 2. & $61-70$ & 3 & 30 \\
\hline & Total & 10 & 100 \\
\hline
\end{tabular}

Sumber : Diolah dari data kuesioner, 2021

Tabel 2 menunjukkan bahwa responden pada umur 50- 60 sebanyak 7 orang dengan persentase sebesar $70 \%$, dan yang terendah pada responden umur 61-70 sebanyak 3 orang dengan persentase $30 \%$. Hal ini menunjukkan bahwa tingkat penyerapan petani dalam penyuluhan pertanian lebih baik karena lebih banyak usia produktif dari pada usia non produktif.

\section{Berdasarkan Pendidikan Terakhir}

Pendidikan menunjukkan tingkat pengetahuan, wawasan, pola pikir, dan perilaku seseorang. Semakin tinggi tingkat pengetahuan seseorang, maka akan semakin tinggi kemampuan seseorang untuk beradaptasi terhadap perubahan yang terjadi. Pendidikan yang dimaksud dalam penelitian ini adalah jenjang pendidikan formal yang pernah diikuti oleh petani responden. Adapun karakteristik responden dalam penelitian ini dapat dijelaskan berdasarkan pendidikan terakhir dan hasil yang diperoleh dapat dilihat sebagai berikut :

\begin{tabular}{|c|c|c|c|}
\hline Tabel & $\begin{array}{l}\text { Karak } \\
\text { Pendi }\end{array}$ & $\begin{array}{l}\text { ristik Responden } \\
\text { kan Terakhir }\end{array}$ & Berdasarkan \\
\hline \multirow[t]{2}{*}{ No. } & \multirow{2}{*}{$\begin{array}{c}\text { Pendidikan } \\
\text { Terakhir }\end{array}$} & \multicolumn{2}{|l|}{$\begin{array}{ll}\text { Jumlah } \\
\end{array}$} \\
\hline & & Responden (Orang) & $\begin{array}{c}\text { Persentase } \\
\%\end{array}$ \\
\hline 1. & SD & 0 & 0 \\
\hline 2. & SMP & 4 & 40 \\
\hline 3.. & SMA & 4 & 40 \\
\hline \multirow[t]{2}{*}{4} & $\begin{array}{l}\text { PERGURUAN } \\
\text { TINGGI }\end{array}$ & 2 & 20 \\
\hline & Total & 10 & 100 \\
\hline
\end{tabular}

Tabel 3 dapat dijelaskan bahwa dari 10 responden yang ada menunjukkan bahwa yang tertinggi pendidikan SMP dan SMA masingmasing sebanyak 4 orang dengan persentase sebesar $40 \%$ dan yang terendah pendidikan yaitu perguruan tinggi 2 orang dengan presentase $20 \%$. sedangkan pendidikan SD tidak ada. Hal ini menunjukkan bahwa penyerapan metode penyuluhan pertanian harus di sesuaikan dengan segmen pendidikan responden di atas.

\section{Analisis Kinerja Penyuluh}

Analisis kinerja petani di Kelurahan Taratara Satu Kecamatan Tomohon Barat Kota Tomohon Provinsi Sulawesi Utara dapat dilihat dari jawaban responden terhadap kuesioner yang ditanyakan kepada sepuluh anggota kelompok tani. Variasi jawaban petani untuk menilai kinerja dari penyuluh di masa pandemi Covid-19 di Desa Taratara Satu.

\section{Program Penyuluhan Pertanian}

Berbagai program penyuluhan pertanian yang dilakukan di Kelurahan Taratara Satu Kecamatan Tomohon Barat. Dari hasil Tabel 4. Menunjukkan bahwa jumlah responden yang memilih baik sebanyak 8 orang dengan persentase sebesar $80 \%$, cukup baik sebanyak 2 orang dengan persentase $20 \%$. Sedangkan tidak baik, tidak di pilih responden.

\begin{tabular}{llcc}
\multicolumn{5}{l}{ Tabel 4. Program Penyuluhan Pertanian. } \\
\hline No & Kriteria & Responden & Presentasi (\%) \\
\hline 1 & Baik & 8 & $80 \%$ \\
2 & Cukup Baik & 2 & $20 \%$ \\
3 & Tidak Baik & - & $0 \%$ \\
\hline & Jumlah & $\mathbf{1 0}$ & $\mathbf{1 0 0 \%}$ \\
\hline
\end{tabular}

Sumber : Diolah dari data kuesioner, 2021 
Hasil baik terlihat dari penilaian petani terhadap kinerja penyuluh dalam menjalankan program penyuluhan pertanian. Ini terjadi karena penyuluh menjalankan setiap program pertanian dalam masa tanam pada tahun 2020. Dibuktikan dengan Rencana Definitif Kebutuhan Kelompoktani (RDKK) yang tetap berjalan selama tahun 2020 meskipun masih dalam masa pandemi Covid-19.

\section{Penyuluh Melakukan Pertemuan Berkala}

Salah satu tugas penyuluh yaitu melakukan pertemuan berkala. Berdasarkan tabel 5 , dapat dilihat bahwa jumlah responden yang memilih baik sebanyak 9 orang dengan persentase sebesar $90 \%$ sedangkan cukup baik sebanyak 1 orang dengan persentase sebesar $10 \%$.

Pertemuan berkala yang dilaksanakan penyuluh pertanian masih dilakukan, tapi harus tetap mengikuti protokol kesehatan yang dianjurkan oleh pemerintah. Hal ini tentunya berpengaruh terhadap penilaian yang dapat dilihat dalam Tabel 5. Menurut petani kegiatan pertemuan berkala yang dilaksanakan oleh penyuluh telah berkurang dibandingkan dengan tahun 2019, dimana pada tahun 2019 tersebut pertemuan atau penyuluhan secara langsung masih bebas dilakukan karena apa yang kita kenal dengan Covid-19 baru masuk ke Indonesia pada awal tahun 2020.

Tabel 5. Penyuluh Melakukan Pertemuan Berkala.

\begin{tabular}{llcc}
\hline No & \multicolumn{1}{c}{ Kriteria } & Responden & Presentasi (\%) \\
\hline 1 & Baik & 9 & $90 \%$ \\
2 & Cukup Baik & 1 & $10 \%$ \\
3 & Tidak Baik & - & $0 \%$ \\
\hline & Jumlah & $\mathbf{1 0}$ & $\mathbf{1 0 0 \%}$ \\
\hline
\end{tabular}

Sumber : Diolah dari data kuesioner, 2021

\section{Pertemuan Teknis, Demonstrasi, dan Kursus Oleh Penyuluh}

Petani yang dari sisi usia yang kebanyakan sudah berumur memerlukan demostrasi, kursus serta pertemuan teknis agar mudah di serap penyuluhannya oleh petani.

Tabel 6. Pertemuan Teknis, Demonstrasi, dan Kursus Oleh

\begin{tabular}{llcc}
\multicolumn{1}{c}{ Penyuluh } & Kriteria & Responden & Presentasi (\%) \\
\hline No & \multicolumn{1}{c}{ Kaik } & 5 & $50 \%$ \\
2 & Cukup Baik & 4 & $40 \%$ \\
3 & Tidak Baik & 1 & $10 \%$ \\
\hline & Jumlah & $\mathbf{1 0}$ & $\mathbf{1 0 0 \%}$ \\
\hline
\end{tabular}

Sumber : Diolah dari data kuesioner, 2021
Tabel 6 menunjukkan bahwa jumlah responden yang memilih baik sebanyak 5 orang dengan persentase sebesar $50 \%$, cukup baik sebanyak 4 orang dengan persentase $40 \%$, tidak baik sebanyak 1 orang dengan persentase sebesar $10 \%$.

Dapat dilihat pada Tabel 6 bahwa pertemuan teknis demonstrasi, dan kursus yang dilakukan oleh penyuluh pertanian dinilai baik oleh petani. Karena dalam masa pandemi Covid19 ini penyuluh masih melakukan pertemuan terkait hal-hal teknis dalam bertani dengan tetap menggunakan protokol kesehatan yang anjurkan oleh pemerintah.

\section{Penyuluh Melakukan Pengembangan Organisasi Petani}

Pengembangan organisasi petani sangat penting untuk meningkatkan produktivitas anggota kelompok tani. Dari hasil di lapangan dapat dilihat :

Tabel 7. Penyuluh Melakukan Pengembangan Organisasi

\begin{tabular}{llcc} 
& Petani & & \\
\hline No & Kriteria & Responden & Presentasi (\%) \\
\hline 1 & Baik & 5 & $50 \%$ \\
2 & Cukup Baik & 5 & $50 \%$ \\
3 & Tidak Baik & - & $0 \%$ \\
\hline & Jumlah & $\mathbf{1 0}$ & $\mathbf{1 0 0 \%}$ \\
\hline
\end{tabular}

Sumber : Diolah dari data kuesioner, 2021

Tabel 7 menunjukkan bahwa jumlah responden yang memilih baik sebanyak 5 orang dengan persentase sebesar $50 \%$, cukup baik sebanyak 5 orang dengan persentase $50 \%$, dan tidak ada responden yang memilih tidak baik.

Dari penilaian petani dalam tabel 7 , hasil baik dan cukup baik memiliki persentase yang sama. Nilai yang diberikan sebagian besar petani tersebut sesuai dengan kinerja penyuluh dalam mengambangkan organisasi dalam kelompok tani, seperti penyuluh masih memberikan pembinaan administrasi di masing-masing kelompok tani. selanjutnya setiap anggota pada kelompok tani yang ada mendapatkan kartu tani yang nantinya bisa digunakan untuk mendapatkan pupuk subsisdi dari pemerintah.

\section{Penyuluh Melatih dan Mengembangkan Kepemimpinan Petani.}

Pelatihan dan pengembangan kepemimpinan petani merupakan salah satu kinerja penyuluh, agar bisa ada petani yang memotivasi anggota kelompok untuk lebih giat meningkatkan produktivitas. Tabel 8 menunjukkan bahwa : 
Tabel 8. Penyuluh Melatih dan Mengembangkan Kepemimpinan Petani

\begin{tabular}{llcc}
\hline No & \multicolumn{1}{c}{ Kriteria } & Responden & Presentasi (\%) \\
\hline 1 & Baik & - & $0 \%$ \\
2 & Cukup Baik & - & $0 \%$ \\
3 & Tidak Baik & 10 & $100 \%$ \\
\hline & Jumlah & $\mathbf{1 0}$ & $\mathbf{1 0 0 \%}$ \\
\hline
\end{tabular}

Sumber : Diolah dari data kuesioner, 2021

Tabel 8 menunjukkan bahwa semua responden memilih tidak baik dengan persentase sebesar $100 \%$, dalam masa pandemi Covid-19 kegiatan penyuluhan oleh penyuluh dibatasi dan kegiatan penyuluhan hanya difokuskan untuk melaksanakan program yang pada intinya adalah kegiatan bercocok tanam seperti demonstrasi teknik bertani dan hal-hal teknis lainnya dalam betani. Dampaknya adalah hasil dari penilaian kinerja pada Tabel 8 adalah sangat tidak baik, dikarenakan pertemuan penyuluh untuk melatih dan mengembangkan kepemimpinan petani sudah tidak lagi dilaksanakan.

\section{Fasilitas Pengembangan Media Informasi untuk Penyuluhan Pertanian}

Fasilitas Pengembangan Media

Informasi untuk Penyuluhan Pertanian sangat penting saat pademi. Media informasi seperti radio, surat kabarm leaflet, TV serta media social lainnya seperti facebook dan whatsup group sangan membantu meningkatkan kinerja penyuluh.

Tabel 9. Fasilitas Pengembangan Media Informasi untuk Penyuluhan Pertanian

\begin{tabular}{llcc}
\multicolumn{4}{c}{ untuk Penyuluhan Pertanian } \\
\hline No & Kriteria & Responden & Presentasi (\%) \\
\hline 1 & Baik & - & $0 \%$ \\
2 & Cukup Baik & - & $0 \%$ \\
3 & Tidak Baik & 10 & $100 \%$ \\
\hline & Jumlah & $\mathbf{1 0}$ & $\mathbf{1 0 0 \%}$ \\
\hline
\end{tabular}

Sumber : Diolah dari data kuesioner, 2021

Tabel 9 menunjukkan bahwa jumlah responden yang memilih tidak baik sebanyak 10 orang dengan persentase sebesar $100 \%$ atau semua responden memilih tidak baik. Dalam Tabel 9, sebagian besar responden menilai kinerja penyuluh sangat tidak baik. Hal ini terjadi dikarenakan tidak ada fasilitas yang diberikan dalam rangka pengembangan media informasi untuk peyuluhan pertanian. Sebelumnya sempat diwacanakan bahwa akan ada sebuah aplikasi berbasis media elektronik yang akan digunakan untuk mempermudah petani mendapatakan informasi mengenai inovasi dan kemajuan dunia pertanian. Dan sampai saat ini aplikasi yang diwacanakan tidak terealisasikan tanpa ada kejalasan padahal dalam masa pandemi Covid-19 saat ini media elektronik seperti itu dapat membantu seorang penyuluh dalam melakukan kegiatan penyuluhan pada petani.

\section{Penyuluh Melatih Petani Dalam Melakukan Kerja Sama dengan Lembaga Lain}

Salah satu tugas pokok penyuluh adalah melatih petani bekerja sama dengan lembaga lain yang bisa membantu meningkatan produksi dan hasil petani. Bekerja sama dengan lembaga lain bisa membuat petani mendapatkan relasi untuk misalnya memasarkan hasil taninya.

Tabel 10. Penyuluh Melatih Petani Dalam Melakukan Kerja Sama dengan Lembaga Lain

\begin{tabular}{llcc}
\hline No & \multicolumn{1}{c}{ Kriteria } & Responden & Presentasi (\%) \\
\hline 1 & Baik & - & $0 \%$ \\
2 & Cukup Baik & - & $0 \%$ \\
3 & Tidak Baik & 10 & $100 \%$ \\
\hline & Jumlah & $\mathbf{1 0}$ & $\mathbf{1 0 0 \%}$ \\
\hline
\end{tabular}

Sumber : Diolah dari data kuesioner, 2021

Semua responden memilih tidak baik sebagai penilaian mereka terhadap tugas pokok penyuluh yang menjadi judul dalam Tabel 10, dengan persentase $100 \%$.

Hasil pada Tabel 10 menjelaskan bahwa kinerja penyuluh penyuluh sangat tidak baik. Ini disebabkan karena memang selama periode tahun 2020 tidak ada pelatihan yang dilakukan oleh penyuluh dalam rangka melatih petani agar dapat melakukan kerja sama dengan lembaga lain.

Selain itu keterbatasan gerak dan protocol kesehatan saat ini juga membuat lembaga lain seperti Koperasi, perbankan dan lembaga lainnya membatasi kerja lapangan mereka. Dalam masa pandemi Covid-19 kegiatan penyuluhan oleh penyuluh dibatasi dan kegiatan penyuluhan hanya difokuskan untuk melaksanakan program yang pada intinya adalah kegiatan bercocok tanam seperti demonstrasi teknik bertani dan hal-hal teknis lainnya dalam betani. 


\section{Studi Banding Antar Kelompok Tani}

Kegiatan studi banding dengan kelompok tannin lain sangat diperlukan bagi petani untuk saling membagi ilmu dan pengalaman. Kegiatan ini biasanya dilakukan dengan saling mengunjungi lahan atau lokasi kelompok tani lain di satu desa, ke desa lain atau ke daerah lain.

Tabel 11 menunjukkan bahwa semua responden memilih tidak baik, persentasenya adalah $100 \%$. Ini karena sudah tidak ada lagi kegiatan studi banding antar kelompok tani dalam masa pandemi ini.

Tabel 11. Studi Banding antar Kelompok Tani

\begin{tabular}{llcc}
\hline No & Kriteria & Responden & $\begin{array}{c}\text { Presentasi } \\
(\%)\end{array}$ \\
\hline 1 & Baik & - & $0 \%$ \\
2 & Cukup Baik & - & $0 \%$ \\
3 & Tidak Baik & 10 & $100 \%$ \\
\hline & Jumlah & $\mathbf{1 0}$ & $\mathbf{1 0 0 \%}$ \\
\hline
\end{tabular}

Sumber : Diolah dari data kuesioner, 2021

Tabel 11, hasil penilaian kinerja yang ada berkaitan dengan tidak adanya studi banding antar kelompok tani. Penyebab utamanya adalah diberlakukannya protokol kesehatan yang wajib dilaksanakan oleh masyarakat termasuk petani. Pada tahuntahun sebelumnya selalu dilaksanakan kegiatan antar kelompok tani seperti perlombaan antar kelompok atau sharing ketika evaluasi hasil panen antar kelompok. Tapi semenjak diberlakukannya protokol kesehatan otomatis semua kegiatan yang dapat mengumpulkan orang banyak tidak disarankan atau dilarang.

\section{KESIMPULAN DAN SARAN}

\section{Kesimpulan}

Kinerja penyuluh pertanian di Kelurahan Taratara Satu, Kecamatan Tomohon Barat, Kota Tomohon berada pada kategori baik tapi ada beberapa program yang tidak berjalan dengan baik. Pada awal masa pandemi Covid19 beberapa kegiatan yang termasuk dalam program tidak dilaksanakan, tapi setelah berjalannya waktu beberapa dari kegiatankegiatan tersebut sudah mulai dilaksanakan.

Saat Pandemi sekarang, kegiatan penyuluhan pertanian yang dilakukan oleh penyuluh pertanian di Kelurahan Taratara Satu hanya berfokus pada kegiatan inti pertanian yaitu bercocok tanam contohnya hal-hal teknis dalam bertani dan demonstrasi dalam bertani.

Kesimpulannya kinerja penyuluh pertanian di Kelurahan Taratara Satu dikategorikan baik dan program yang berjalan sesuai dengan Rencana Definitif Kebutuhan Kelompoktani (RDKK) walaupun ada beberapa yang tidak dilaksanakan.

\section{Saran}

1. Penyuluh harus tetap melaksanakan semua program sesuai RDKK dengan mengikuti protokol kesehatan yang di anjurkan oleh pemerintah, seperti mencuci tangan, menjaga jarak, dan memakai masker. Petani sangat membutuhkan peran penyuluh dalam perkembangan skil dan pengetahuan dalam dunia pertanian, oleh karena itu penyuluh harus tetap membimbing para petani.

2. Penyuluh harus memfasilitasi petani lewat media informasi, ini adalah salah satu cara melaksanakan penyuluhan dalam masa pandemi tanpa harus melibatkan banyak orang dalam satu pertemuan.

\section{DAFTAR PUSTAKA}

Badan Pusat Statistik. 2020. Pertumbuhan Ekonomi Indonesia Triwulan II-2020. No 64/08/Th.XXIII 5 Agustus 2020. Jakarta (ID): Badan Pusat Statistik.

Gitosaputro, S., Listiana I., Gultom DT. 2012. Dasar-dasar Penyuluh dan Komunikasi Pertanian.

Kartasapoetra G.A. 1994. Teknologi penyuluhan Pertanian. Bumi Aksara. Jakarta. 
Kementerian Pertanian. 2014. Kebijakan Pembangunan Pertanian 2015- 2016. Kementrian Pertanian. Jakarta.

Nuryanto BG. 2008. Kompetensi penyuluh dalam pembangunan pertanian di Provinsi Jawa Barat [disertasi]. Bogor (ID): Institut Pertanian Bogor.

Sondang Siagian. 2002. Manajemen SDM. Jakarta: Bumi Aksara. 